\title{
ANALYSIS OF ACTIVE COMPOUNDS in BLOOD PLASMA OF MICE AFTER INHALATION OF CAJUPUT ESSENTIAL OIL (Melaleuca leucadendron L.)
}

\author{
Muchtaridi*, Ami Tjiraresmi, Riska Febriyanti
}

Department of

Pharmaceutical Analysis and Medicinal Chemistry, Faculty of Pharmacy, Universitas Padjadjaran, Jl. Jatinangor KM 21Sumedang.

Submitted: $09-07-2015$

Revised: $13-08-2015$

Accepted: 20-10-2015

*Corresponding author Muchtaridi

Email: muchtaridi@unpad.ac.id

\begin{abstract}
The research is intended for the determination of volatile compounds of cajuput oil (Melaleuca leucadendron L.) in a group of mice (3 mice) after inhaling $1 \mathrm{~mL}$ cajuput oil for $1 / 2,1$ and $2 \mathrm{~h}(\mathrm{~s})$. The blood plasma of three mice was collected in heparin tube, and the volatile compounds were isolated and concentrated using C-18 Solid Phase Extraction (SPE) column with methanol and bidistilled water mixture $(60: 40)$ as the solvent. The analysis was carried out by GC/MS. The results showed that there were 52 compounds in the cajuput oil, especially 1,8 -cineole, $\alpha$-terpineol, $\beta$ pinene, $\alpha$-pinene, $\beta$-myrcene, 4-terpineol, linalool, $\gamma$-terpinene, and terpinolene. The major compound identified in blood plasma of mice was 1,8 -cineole. Half an hour after $1 \mathrm{~mL}$ inhalation of cajuput oil per mouse, the concentration of 1,8-cineole identified was $41.5 \mu \mathrm{g} / \mathrm{mL}$, while 1 and $2 \mathrm{~h}$ after $1 \mathrm{~mL}$ inhalation of cajuput oil, the level of 1,8 -cineole in blood plasma of 3 mice was $646.9 \mu \mathrm{g} / \mathrm{mL}$ and $138.0 \mu \mathrm{g} / \mathrm{mL}$ in blood plasma of each mouse. Other compounds identified were $\alpha$-terpineol, 4-terpineol linalool, terpenyl acetate and hydrocarbon terpenes. Concentrations of target compounds in the blood plasma were relatively in low level $(\mu \mathrm{g} / \mathrm{mL})$. In conclusion, the volatile compounds of 4-terpineol, linalool, $\alpha$-terpineol and 1,8-cineol that identified in blood plasma of mice after inhalation of the cajuput oils might correlate with depressive characteristics of essential oil given by inhalation.
\end{abstract}

Key words: Cajuput, Essential Oils, Inhalation, SPE, GC-MS

\section{INTRODUCTION}

Essential oil has been utilized for perfumes, cosmetics, food additives and drugs (Buchbauer, 2000). It has been proven that aromatic compounds or fragrance of essential oil of a plant material can affect locomotor activity (Buchbauer et al., 1991; Buckle, 1999; Diego et al., 1998; Martin, 1998). The research on essential oil that has an effect on locomotor activity is initiated by Kovar et al. (1987) reporting that isolated compound of 1,8 cineol from essential oil in rosemary can increase locomotor activity of mice. According to Buchbaurer, et al. (1991), volatile compounds identified in blood plasma are expected to be active components that are responsible for pharmacological activity in affecting the central nervous system (CNS). It is due to compounds that stimulate CNS work on Blood-Brain Barrier (BBB) or cross the blood-brain (Buchbauer 2004).
Ethnopharmacology study regarding aromatherapy plants showed that Indonesia has 12 types of aromatic plants used empirically which have refreshing and relaxing effects (anxiolytic) for physical healthy (Sangat and Roematyo 1996). Cajuput (Melaleuca leucadendron L.) is one of Indonesian aromatic plants, especially in Java (Heyne 1987). Cajuput contains essential oil about $0.80-1.00 \% \mathrm{v} / \mathrm{b}$, with a density ranging from $0.910-0.923 \mathrm{~g} / \mathrm{cm}^{3}$ (FI III, 1979).

Applying cajuput oil orally (Wiendah, et al., 1999) and inhalation (Muchtaridi, et al., 2011), in fact, can reduce locomotor activity of mice, although 1,8-cineol is the dominant component in cajuput oil. In this study, the application of SPE has been used for chemical analysis of essential oil compounds in the blood of mice after the inhalation of cajuput essential oil (Melaleuca leucadendron L.). The findings from this study suggest that the 4-terpineol, 
linalool, $\alpha$-terpineol and 1,8-cineol might correlate with the locomotor activity of mice.

1,8-cineol compound is the main component in cajuput essential oil, followed by $\alpha$-terpineol, linalool and other terpens from cyclic and acyclic groups (Muchtaridi et al., 2011). According to Koyar (Kovar et al., 1987) and Balchin (Lis-Balchin, 1999), 1,8-cineol can boost locomotor activity of mice and rats, while $\alpha$-terpineol and linalool reduce the locomotor activity (Buchbauer and Jirovetz, 1994).

The aim of this research is to identify active compounds in cajuput oil that are responsible for reducing locomotor activity.

\section{MATERIAL AND METHODS}

Eucalyptus leaves (Meulaleuca leucadendron Linn) were taken from Kuningan, West Java. Specimens are identified by the Herbarium Laboratory, Department of Biology, Faculty of Mathematics and Natural Sciences, Universitas Padjadjaran, Bandung, Indonesia and voucher specimens are stored in the Herbarium of Biology Department, Faculty of Mathematics and Natural Sciences, Universitas Padjadjaran.

The sample herbs dried (500g) were water-distilled at Balitro, Monaco Lembang for $3 \mathrm{~h}$. The oil was stored at $-20^{\circ} \mathrm{C}$ after addition of sodium sulphate (Sigma, USA). Essential oil of eucalyptus leaves obtained was $2.31 \%$.

Animals-Male mice weighing 25 to $30 \mathrm{~g}$ and 2 to 3 months old were used. The mice were adapted for one week to the laboratory in which locomotor activity experiments were conducted and were selected for wheel rotations of between 150 to 300 before the experiments were started. All experimental procedures for animal use have been approved by the Ethical Committee of Experimental Animals, Universitas Padjadjaran.

Chemicals-Methanol pro.analyse (Merck, Germany) was used as a mobile phase for SPE. Heparin tubes (Boehringer, Germany) were used for blood collection. Pure lavender (Lavandula officinalis) oils were obtained from Martina Bertho (Indonesia). Alkane standards $\mathrm{C}_{8}-\mathrm{C}_{20}, \quad \mathrm{C}_{21}-\mathrm{C}_{40}, \quad$ 1,4-dichlorobenzene from Sigma (USA), and 4-terpineol, linalool, $\alpha$ terpineol dan 1,8-cineol were obtained from Dragoco (France).
Identifying compounds of blood plasma

Collecting blood plasma of mice is based on the method performed by Jirovetz et al. (1992), Kovar et al., 1987, and Muchtaridi et al., 2011). Please see the instruction for authors for reference style.

\section{Isolation of essential oils}

Dried samples of each plant (500g) were submitted to water-distillation in Monaco Lembang, West Java, for $3 \mathrm{~h}$ to isolate the essential oils. The oils were stored at $-20^{\circ} \mathrm{C}$ after the addition of sodium sulphate (Muchtaridi et al., 2014).

\section{Mouse locomotor activity tests}

Locomotor activity of mice was measured using a wheel cage, in which mice ran and the number of rotations was recorded by a meter. Cage inhalators contained a glass fiber $(20 \mathrm{~cm} \times 20 \mathrm{~cm} \times 30 \mathrm{~cm})$ and were equipped with an electric fan for the evaporation and distribution of volatile compounds. The mice were selected by weight ( 25 to $30 \mathrm{~g}$ ) and by their ability to rotate the wheel cage up to 300 times in $30 \mathrm{~min}$; eligible mice were then divided into three groups: a control group, a lavender oil group as positive control group (using 0.1, 0.3 and $0.5 \mathrm{~mL} /$ cage), and a essential oils tested as treatment group (using 0.1, 0.3, and $0.5 \mathrm{~mL} /$ cage). The application of the doses were based on the preliminary examination in which those doses were reasonable to be used and based on Kovar et al., (Kovar et al., 1987). Each group consisting of five mice was tested three separate times. After $30 \mathrm{~min}$ of inhalation, the mice were placed into the wheel cage and after $5 \mathrm{~min}$; the number of rotations were recorded for $75 \mathrm{~min}$ in $15 \mathrm{~min}$ intervals.

\section{GC/MS analysis}

Analyses have been done according to a previously published method. Measurements were performed using a Shimadzu QP-5050A gas chromatograph coupled to a VG Autospec Mass Spectrometer at 70eV, 40-550amu with a fused silica capillary column (DB-5MS, $30 \mathrm{~m} \times 0.25 \mathrm{~mm}$ ) using helium as a carrier gas and with temperature programming from $60^{\circ} \mathrm{C} / 5 \mathrm{~min}$ to $300^{\circ} \mathrm{C} / \mathrm{min}\left(10^{\circ} \mathrm{C} / \mathrm{min}\right)$ for blood plasma and $60^{\circ} \mathrm{C} / 5 \mathrm{~min}$ to $300^{\circ} \mathrm{C} / 2 \mathrm{~min}$ 
$\left(10^{\circ} \mathrm{C} / \mathrm{min}\right)$ for essential oils. The MS was operated using an interface temperature of $240^{\circ} \mathrm{C}$, and an electron impact ionization of $70 \mathrm{eV}$ with a scan mass range of $40-350 \mathrm{~m} / \mathrm{z}$ (sampling rate of $1.0 \mathrm{scan} / \mathrm{s}$ ).

\section{Qualitative analysis}

Identification of the compounds was conducted by comparing their linear retention indices (LRI) with literature values and their mass spectral data with those from the MS data system (Wiley-229 lib, Nist-62 library and Nist-12 library) (Adams 1995). Linear retention indices were calculated using GC data of a homologous series of saturated aliphatic hydrocarbons ( $\mathrm{C}_{8}$ to $\mathrm{C}_{40}$ ) separated on the same column using the same conditions as for GC analysis of the essential oils and the blood samples. The blood samples were collected from the corner parts of the eyes using capillary tubes and placed in a heparin tube. Blood samples were collected immediately after the mice inhaled the essential oil for a period of $1 / 2,1$ or $2 \mathrm{~h}$.

\section{Quantitative analysis}

Detailed analysis using methods were performed in Kovar et al., 1987; Jirovetz et al., 1992; and Jirovetz et al., 1991 with modification. The blood samples (500 to $600 \mu \mathrm{L})$, obtained according to Jirovetz (Jirovetz et al., 1992), were centrifuged $(1.800 \mathrm{rpm} / 10 \mathrm{~min})$ at room temperature and

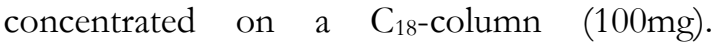
Volatile compounds were separated using a mobile phase of the mixture of methanolbidistilled water (60:40). Five micro-litres reinjected into the GC-MS. Quanti-fication of the volatile compounds in the blood samples was accomplished using 1,4-dichloro-benzene 0.5\% $(500 \mu \mathrm{L})$ as an internal standard as according to the following equation:

$[C]=\frac{A}{I S} \times \frac{I S \text { weight }(g)}{100 m L} \times \% E O \times I S$ volume $\times 10^{6}$

where: $C=$ concentration $(\mathrm{g} / \mathrm{g})$; IS = GC peak area of Internal Standard; $A=\mathrm{GC}$ peak area of compounds of essential oils; $\% E O=$ yield of essential oils.

\section{Determining of LRI and Concentration}

Confirming identity of identification result has been carried out by determining (Linear Retention Index) LRI value. This value is calculated based on standard retention time of alkanes $\left(\mathrm{C}_{8}-\mathrm{C}_{40}\right)$ which is injected in $\mathrm{GC}-\mathrm{MS}$ with the same condition and column.

Five microliters were injected into the GC-MS. Quantification of the volatile compounds in the blood samples was accomplished using 1,4-dichlorobenzene 0.5\% ( $5 \mathrm{mg}$ in $1 \mathrm{~mL}$ blood plasma) as an internal standard according to the following equation (1)(Muchtaridi et al., 2010):

$[C]=\frac{A}{I S} \times \frac{I S \text { weight }(g)}{100 m L} \times \% E O \times I S$ volume $\times 10^{6}$

$C=$ concentration $(\mathrm{g} / \mathrm{g}) ; I S=$ GC peak area of Internal Standard; $A=$ GC peak area of compounds of essential oils; \% EO = yield of essential oils.

Recovery is calculated based on the ratio between the concentration of 1,4dichlorobenzene in blood plasma and the concentration of 1,4-dichlorobenzene in methanol (blank) by repeating it twice.

\section{RESULT AND DISCUSSION \\ Analysis of cajuput essential oil components \\ Cajuput essential oil (Melaleuca} leucadendron Linn.) obtained from $1.3 \mathrm{~kg}$ of dried cajuput leaves was $30 \mathrm{~mL}$. Cajuput essential oil yield was $2.31 \% \mathrm{v} / \mathrm{b}$. Essential oil obtained had yellowish translucent colour and typical smell. The compound of 1.8-cineole dominated the composition of cajuput essential oil leaves about $22.45 \%$. That level was smaller as compared to the data in Proscea (30-50\%) (Oyen Nguyen, 1999). According to its great level, the following components are $\alpha$-terpineol $(12.45 \%)$, caryophillene $(6.95 \%), \quad \beta$-pinene (5.74\%), $\alpha$-humulene $(4.70 \%), \quad \beta$-selinene $(3.82 \%), \beta$-myrcene $(3.58 \%), \alpha$-selinene $(2.9 \%)$, and $\alpha$-terpenyl acetate $(2.74 \%)$. To be specific, it can be seen (Table III).

\section{Analysis of essential compounds in blood plasma of mice after the inhalation of cajuput oil}

To know the effects of cajuput essential oil on locomotion, this oil was administered to mice via inhalation. Doses of $0.1,0.3$, and $0.5 \mathrm{~mL} /$ cage could decrease on locomotor activity by $46.81 \%, 69.47 \%$, and $62.04 \%$, respectively (Table III). 
Table I. Essential compounds identified in blood plasma of mice after the inhalation of nutmeg seed oil with SPE C-18 preparation, analyzed by GC-MS.

\begin{tabular}{|c|c|c|c|c|c|c|c|c|}
\hline \multirow{3}{*}{$\begin{array}{l}\text { Peak } \\
\text { No }{ }^{d}\end{array}$} & \multirow[b]{3}{*}{ Compounds } & \multicolumn{6}{|c|}{ Duration of Inhalation } & \multirow{3}{*}{$\begin{array}{l}L R I \\
\mathbf{R e f}^{\mathbf{a}}\end{array}$} \\
\hline & & \multicolumn{2}{|c|}{$1 / 2$ hours $\left(\mathrm{R}^{\mathrm{c}}=81 \%\right)$} & \multicolumn{2}{|c|}{1 hours $\left(\mathrm{R}^{\mathrm{c}}=91 \%\right)$} & \multicolumn{2}{|c|}{2 hours $\left(\mathrm{R}^{\mathrm{c}}=88 \%\right)$} & \\
\hline & & $\begin{array}{l}\text { LRI } \\
\text { Exp }^{b}\end{array}$ & $\begin{array}{c}\text { Concentration } \\
\mu \mathrm{g} / \mathrm{mL}\end{array}$ & $\begin{array}{c}\text { LRI } \\
\operatorname{Exp}^{b}\end{array}$ & $\begin{array}{c}\text { Concentration } \\
\mu \mathrm{g} / \mathrm{mL}\end{array}$ & $\begin{array}{c}\text { LRI } \\
\text { Exp }^{b}\end{array}$ & $\begin{array}{c}\text { Concentration } \\
\mu \mathrm{g} / \mathrm{mL}\end{array}$ & \\
\hline 1. & $\alpha$-Pinene & nd & nd & 936 & 24.9 & nd & nd & 939 \\
\hline 2. & Benzaldehyde & nd & nd & 969 & 11.4 & nd & nd & 961 \\
\hline 3. & $\beta$-Pinene & nd & nd & 989 & 23.3 & nd & nd & 980 \\
\hline 4. & Limonene & nd & nd & 1034 & 53.7 & 1032 & 13,4 & 1031 \\
\hline 5. & 1,8-Cineole & 1037 & 41.5 & 1037 & 646.9 & 1035 & 138.0 & 1033 \\
\hline 6. & $\Delta$-Carene & nd & nd & 1057 & 15.9 & nd & nd & 1011 \\
\hline 7. & $\alpha$ Terpinolene & nd & nd & 1080 & 9.1 & nd & nd & 1088 \\
\hline 8. & Linalool & nd & nd & 1090 & 17.6 & nd & nd & 1098 \\
\hline 9. & 4-Terpineol & nd & nd & 1165 & 17.6 & 1170 & 2.6 & 1177 \\
\hline 10. & $\alpha$-Terpineol & 1177 & 13.3 & 1177 & 208.7 & 1179 & 35.5 & 1189 \\
\hline 11. & Linalyl acetate & nd & nd & 1281 & $t d$ & 1260 & 5.2 & 1257 \\
\hline 12. & $\alpha$-Terpenyl acetate & nd & nd & 1283 & 24.9 & nd & nd & 1350 \\
\hline 13. & (E)-Cariophyllen & nd & nd & 1417 & 9.4 & nd & nd & 1418 \\
\hline
\end{tabular}

$n d=$ no detection, a: LRI reference in Adams (1995) with DB5-MS column, b : LRI_experiment with DB5-MS column, c: Recovery, d: Number of peak in line with number of the peak on GC chromatogram (Figure 1)

Table II. Average number of mice wheel cage rotations within $90 \mathrm{~min}$ of inhalation of nutmeg and lavender essential oils.

\begin{tabular}{ccc}
\hline Tratment & $\begin{array}{c}\text { The Average number of mice wheel } \\
\text { cage rotations (Averages } \pm \mathbf{~ S D )}\end{array}$ & Decreasing of Activity (\%) $^{* *}$ \\
\hline Normal Control & $285.63 \pm 32.22$ & 0 \\
Lavender $0.1 \mathrm{~mL}$ & $214.67 \pm 32.19^{*}$ & 24.84 \\
Lavender $0.2 \mathrm{~mL}$ & $171.47 \pm 17.50^{*}$ & 39.97 \\
Lavender $0.3 \mathrm{~mL}$ & $151.43 \pm 15.16^{*}$ & 46.91 \\
Cajuput $0.1 \mathrm{~mL}$ & $151.93 \pm 46.16^{*}$ & 46.81 \\
Cajuput $0.2 \mathrm{~mL}$ & $87.20 \pm 33.95^{*}$ & 69.47 \\
Cajuput $0.3 \mathrm{~mL}$ & $108.43 \pm 45.53^{*}$ & 62.04 \\
\hline
\end{tabular}

$*=$ There were significantly different with normal $(\alpha=5 \%)$

$* *=$ The decreasing score was compared than normal control $(0 \%)$

Thus, the effect of cajuput oil on locomotion was dose-dependent. A strong inhibitory effect of the cajuput oil on locomotion was observed;

As the previous study, we compared the activity of cajuput oil to that of lavender oil as a positive control, because lavender oil has been proven to decrease locomotion of female and male laboratory animals (Muchtaridi et al., 2010). As shown in table $I$, cajuput oil afforded a greater inhibitory effect than lavender oil did. The inhalation of cajuput oil reduced the locomotor activity of mice up to $69.47 \%$ (Table II).

Compounds of 1.8-cineole, $\alpha$-terpineol and 4-terpineol were the three dominant compounds in blood plasma of mice after inhaling cajuput leaves. The result of identifying essential compounds in blood plasma of mice after inhaling cajuput leaves (Figure 1). 

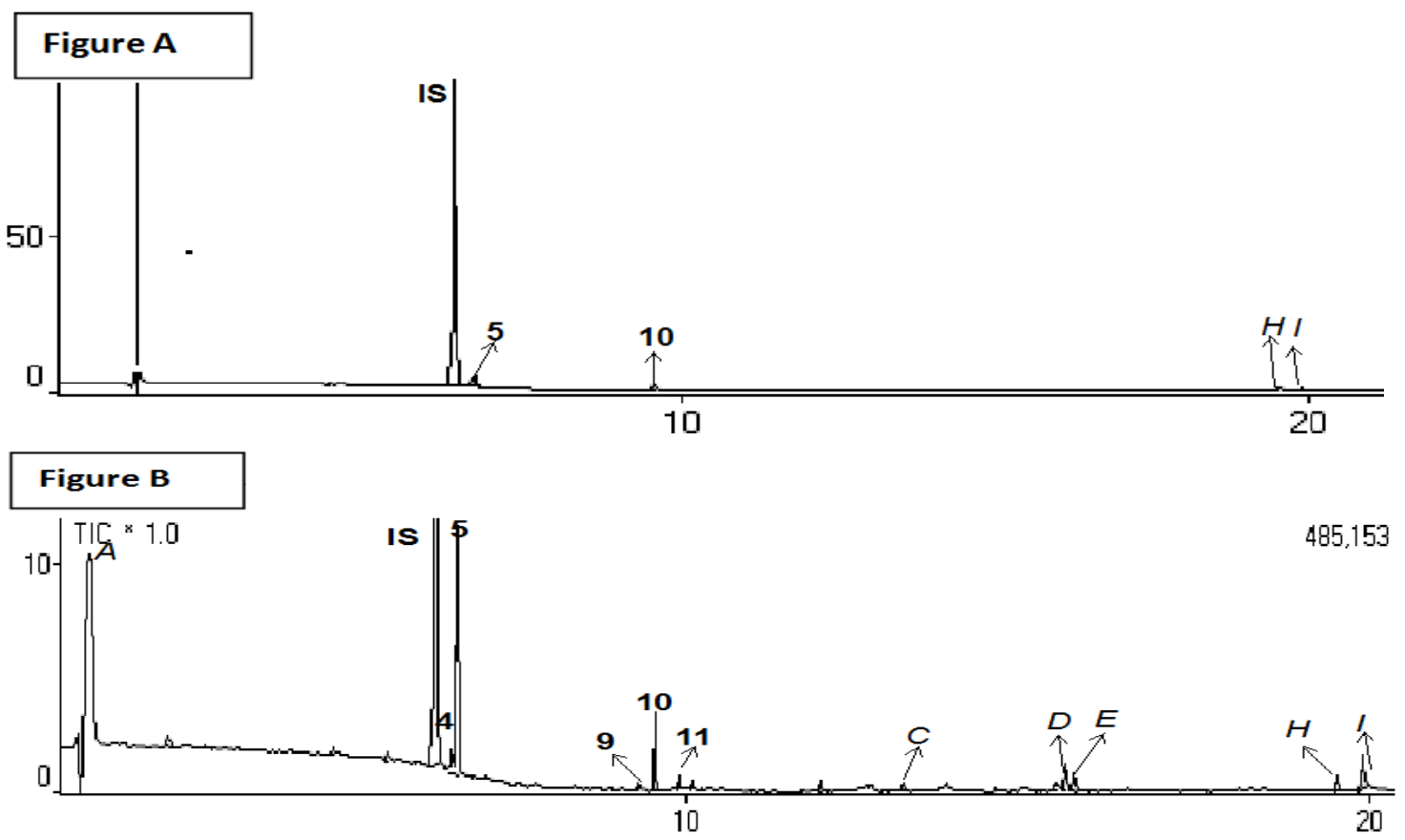

Figure 1. Total ion chromatogram of essential oil compounds in blood plasma of mice after inhaling essential oil of cajuput leaves. Figure A shows the chromatogram of essential compound after $1 / 2 \mathrm{~h}$ inhalation, while figure $\mathbf{B}$ shows the chromatogram of essential comp

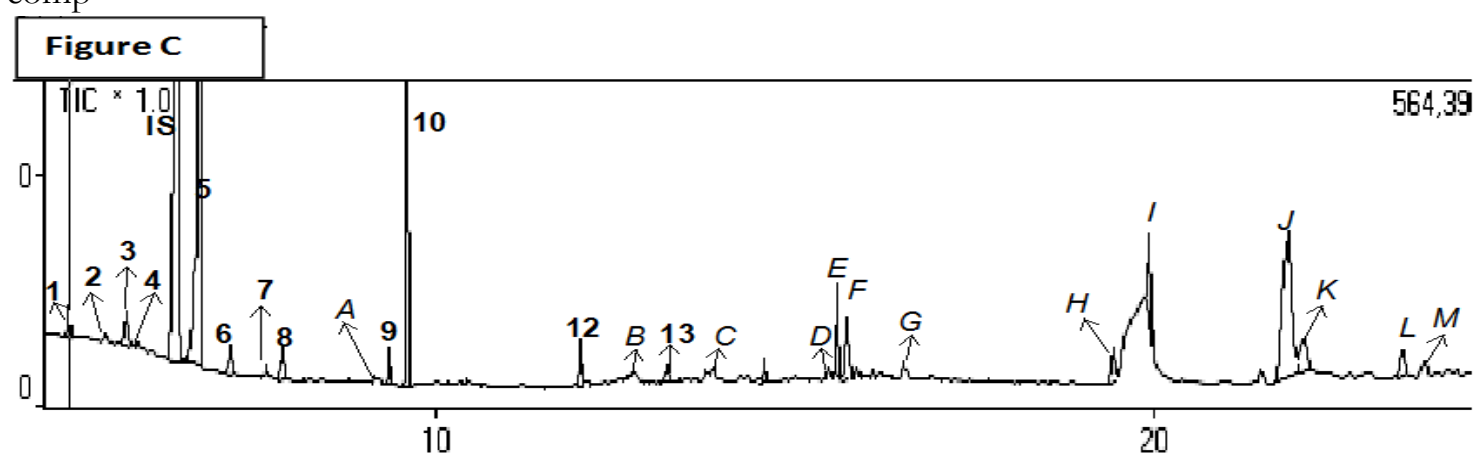

ounds after $1 \mathrm{~h}$ inhalation, and figure $\mathbf{C}$ shows the chromatogram of essential compounds after $2 \mathrm{~h}$ inhalation. IS: Internal Standard. The peak which is indicated by A to M is such compounds other than essential oil (Table II).

In figure 1 , the peak no.5 (1,8-cineole) always seems to appear with the largest concentration, followed by the peak no.10 ( $\alpha$ terpineol). On the other hand, the peak no.9 (4-terpineol) appears in figure A (blood plasma of mice after $1 / 2 \mathrm{~h}$ inhalation of cajuput oil) and B (blood plasma of mice after $1 \mathrm{~h}$ inhalation of cajuput oil). These compounds are allegedly considered as active compounds that are responsible for inhibiting locomotor activity. It is proved by the previous research (Kovar, et al., 1987; Aoshima, et al., 2001). Active compounds in essential oil are responsible for the decrease of locomotor activity for each different essential oil, depending on the composition of the essential oil. Identified compounds in blood with the high bioavailability at $30 \mathrm{~min}$ to $2 \mathrm{~h}$ is allegedly expected to be responsible for the pharmacological activity of essential oil, or called as the lead compound (Buchbauer et al., 1993). 
Table III. Chemical composition of the essential oil of Cajuput (Meulaleuca lecadendron Linn.)

\begin{tabular}{cccccc}
\hline Peak No & Retention Time & LRI Exp $^{\mathbf{a}}$ & LRI Ref $^{\mathbf{b}}$ & Compounds & \% Area \\
\hline 2 & 6.542 & 940 & 939 & $\alpha$-Pinene & 5.25 \\
3 & 6.914 & 953 & 953 & Camphene & 0.04 \\
4 & 7.775 & 984 & 980 & $\beta$-Pinene & 5.74 \\
5 & 8.035 & 993 & 991 & $\beta$-myrcene & 3.58 \\
6 & 8.392 & 1007 & 1031 & L-Limonene & 0.14 \\
7 & 9.168 & 1038 & 1033 & 1.8 -Cineole & 22.45 \\
10 & 9.81 & 1063 & 1062 & $\gamma$-Terpinene & 1.54 \\
11 & 10.343 & 1085 & 1088 & Terpinolene & 0.98 \\
13 & 10.66 & 1097 & 1098 & Linalool & 1.71 \\
14 & 10.833 & 1106 & 1111 & Rose oksida & 0.04 \\
17 & 11.63 & 1148 & 1146 & Isopulegol & 0.13 \\
19 & 12.074 & 1172 & 1177 & 4 -Terpineol & 1.71 \\
20 & 12.31 & 1185 & 1189 & $\alpha$-Terpineol & 12.45 \\
23 & 13.326 & 1243 & 1240 & Neral & 0.24 \\
24 & 13.489 & 1253 & 1255 & Geraniol & 0.13 \\
25 & 13.811 & 1272 & 1270 & Geranial & 0.31 \\
28 & 14.582 & 1318 & 1350 & $\alpha$-Terpenyl acetate & 0.14 \\
30 & 14.964 & 1342 & 1339 & $\Delta$-Elemene & 0.23 \\
31 & 15.18 & 1356 & 1350 & $\alpha$-Terpenyl acetate & 2.75 \\
33 & 15.557 & 1380 & 1372 & $\alpha$-Ylangene & 0.37 \\
34 & 15.653 & 1386 & 1351 & $\alpha$-Cubebene & 0.36 \\
36 & 15.856 & 1398 & 1391 & $\beta$-Elenene & 1.01 \\
37 & 16.156 & 1419 & 1409 & $\alpha$-Gurjunene & 0.16 \\
38 & 16.489 & 1441 & 1418 & (E)-Caryophillen & 6.95 \\
39 & 16.67 & 1453 & 1439 & Aromadendrene & 0.45 \\
41 & 17.004 & 1476 & 1454 & $\alpha$-Humulene & 4.7 \\
42 & 17.146 & 1486 & 1485 & $\gamma$-Selinene & 0.95 \\
44 & 17.483 & 1509 & 1485 & $\beta$-Selinene & 3.82 \\
45 & 17.573 & 1516 & 1494 & $\alpha$-Selinene & 2.9 \\
46 & 17.762 & 1529 & 1524 & $\Delta$-Cadinena & 0.98 \\
51 & 18.286 & 1567 & 1581 & Caryophillen oxide & 0.21 \\
52 & 18.414 & 1577 & 1556 & Germacrene B & 0.97 \\
55 & 18.797 & 1605 & 1583 & Globulol & 2.94 \\
56 & 18.97 & 1618 & 1590 & Viridiflorol & 3.52 \\
61 & 19.395 & 1651 & 1630 & $\gamma$-Eudesmol & 1.81 \\
64 & 19.761 & 1679 & 1649 & $\beta$-Eudesmol & 3.63 \\
\hline & & & &
\end{tabular}

a LRI reference in Adams (1995) with DB5 column

b LRI experiment with DB5-MS column

The highest level of 1,8-cineole in the inhalation of cajuput essential oil was in $1 \mathrm{~h}$ inhalation, but rapidly declined in $3 \mathrm{~h}$ inhalation. It means that in $2 \mathrm{~h}$ after the essential components reached circulatory system, the components are immediately distributed into tissues and metabolized or have been eliminated either entirely or partially through 
urine, lungs or other elimination routes, thus the concentration in blood is very small and cannot be identified. After 1,8-cineole began to secrete for $2 \mathrm{~h}$, either through urine or sweat, 1,8-cineole gives a strong spasmolytic effect by inducing acetyl choline (Buchbauer et al., 1993). Single compound of 1,8-cineole boosts locomotor activity or stimulation to $\mathrm{CNS}$, but when it interact in essential oil, this compound will synergize with alcohol terpen as well as 4terpineol that reduces locomotor activity (Aoshima et al., 2001; Buchbauer et al., 1993b) and synergizes with $\alpha$-pinen by reducing smooth muscle strain (spasmodic).

$\alpha$-terpineol and 4-terpineol compounds give the same effect on GABA system. Through these compounds, $\mathrm{GABA}_{\mathbf{A}}$ receptor potentiality is very strong in small concentration. 4-Terpineol gives stronger activity as compared to $\alpha$-terpineol (Aoshima, et al., 2001).

\section{Recovery analysis using SPE}

The effectiveness of SPE in the analysis of volatile compounds in blood after the inhalation of essential oil has been explained in the previous publication (Muchtaridi and Musfiroh 2012). The recovery on the analysis of 1.8-cineole in blood plasma of mice after inhaling nutmeg seed oil using $C_{18}$ (Sep Pak Waters) reaches $90 \%$ in comparison to untreated SPE. In addition, other volatile compounds are greatly detected (Table I).

The use of SPE in the research is not able yet to reduce all impurities. Figure 1, the peak $A$ to $M$ is compounds other than essential compounds. However, the origin of the nonessential compounds has not been clearly explained in the research. As well as the nonessential compounds in blood plasma of mice after the inhalation of basil oil, contaminant compounds detected in blood plasma of mice possibly come from contamination of plastic container (peak D, H and I). In addition, there are also no alcohol sesquiterpen compounds in cajuput essential oil, such as viridflorol and palustrol. It is expected that the compounds probably come from the previous injection sample in GC-MS (Table III).

\section{Locomotor activity of mice in regard to single compound identified}

The locomotor activity of mice in regard to single compound identified in blood after the inhalation of cajuput leaves oil was tested to ensure that identified compounds influence on the locomotor activity of mice. Linalool, $\alpha$ terpineol and 1,8-cineol compounds reduced locomotor activity of mice as compared to nomal control $(100 \%)$ (figure 1).

Essential oil of cajuput leaves inhalation provides a greater decline than a single compound of 4-terpineol, linalool, $\alpha$-terpineol and 1,8-cineol. However, all single compounds generally reduce locomotors activity towards normal. Only 1,8-cineol compound has insignificant activity in comparison to normal control. Moreover, 1,8-cineol with $0.5 \mathrm{~mL}$ dose gives stimulant effect towards central nervous system of mice (CNS). These results indicated that 4-terpineol, linalool, $\alpha$-terpineol and 1,8cineol that identified in blood plasma of mice after inhalation of the cajuput oils might correlate with depressive characteristics of essential oil given by inhalation.

According to Kovar, et al., (1987), 1,8cineole gives CNS stimulant activity of mice. The greater dose given will remain the greater stimulant effect produced. Besides, these findings are in line with the research conducted by Aoshima et al. (2001) and Buchabuer et al. (1993) who state that 4-terpineol, linalool and $\alpha$-terpineol boost the affinity of GABA work system.

\section{CONCLUSION}

Essential oil compounds detected in blood with a dominant duration were 4terpineol, linalool, $\alpha$-terpineol, and 1,8-cineole. This study reported that the volatile compounds detected in blood samples such as 4-terpineol, linalool, $\alpha$-terpineol and 1,8-cineol were related with inhibition of locomotor activity in mice. It is suggested that the locomotor inhibition by cajuput essential oil is due, at least in part, to the direct pharmacological action of one or more of its constituents. 


\section{REFERENCES}

Adams RP., 1995, Identification of Essential Oil Components by Gas Chromatography/Mass Spectroscopy. Illinois: Allured Publishing Corporation.

Aoshima H., Hossain SJ., Hamamoto K., Yokoyama T., Yamada M., Shingai R.. 2001, Kinetic analyses of alcoholinduced potentiation of the response of GABA(A) receptors composed of alpha(1) and beta(1) subunits. Biochem 130 (5):703-709.

Buchbauer G., 2004, On the biological properties of fragrance compounds and essential oils. Wien Med Wochenschr 154 (21-22):539-547.

Buchbauer G., Jäger W., Jirovetz L., Ilmberger J., Dietrich H. 1993. Therapeutic Properties of Essential Oils and Fragrances. In Bioactive Volatile Compounds from Plants: American Chemical Society, 159-165.

Buchbauer G., Jirovetz L. 1994, Aromatherapyuse of fragrances and essential oils as medicaments. J Flav Frag 9 (5):217-222.

Buchbauer G., Jirovetz L., Jager W., H. Dietrich, and C. Plank. 1991, Aromatherapy: evidence for sedative effects of the essential oil of lavender after inhalation. Z Naturforsch C 46 (1112):1067-1072.

Buckle J., 1999, Use of aromatherapy as a complementary treatment for chronic pain. Altern Ther Health Med 5 (5):42-51.

Diego M., A., Jones NA., Field T., HernandezReif M., Schanberg S., Kuhn C., McAdam V., Galamaga R., Galamaga M. 1998, Aromatherapy positively affects mood, EEG patterns of alertness and math computations. Int. J. Neurosci 96 (34):217-224

Heyne K., 1987, Tumbuhan Berguna Indonesia. Jakarta: Yayasan Sarana Wijaya.

Jirovetz L., Buchbauer G., Jager W., Woidich A., Nikiforov A. 1992, Analysis of fragrance compounds in blood samples of mice by gas chromatography, mass spectrometry, GC/FTIR and GC/AES after inhalation of sandalwood oil. Biomed Chromatogr 6 (3):133-134.

Jirovetz L., Jager W., Buchbauer G., Nikiforov A., Raverdino V. 1991, Investigations of animal blood samples after fragrance drug inhalation by gas chromatography/mass spectrometry with chemical ionization and selected ion monitoring. Biol Mass Spectrom 20 (12):801-803.

Kovar KA., Gropper B., Friess D., Ammon HP. 1987, Blood levels of 1,8-cineole and locomotor activity of mice after inhalation and oral administration of rosemary oil. Planta Med 53 (4):315-318.

Lis-Balchin M., 1999, Possible health and safety problems in the use of novel plant essential oils and extracts in aromatherapy. The journal of the Royal Society for the Promotion of Health 119 (4):240-243.

Martin GN., 1998, Human electroencephalographic (EEG) response to olfactory stimulation: two experiments using the aroma of food. Int I Psychophysiol 30 (3):287-302.

Muchtaridi M., Diantini A., Subarnas A. 2011, Analysis of Indonesian Spice Essential Oil Compounds That Inhibit Locomotor Activity in Mice. Pharmacenticals 4 (4):590602.

Muchtaridi M., Musfiroh I. 2012, Off-Line SPE-GC/MS Analysis of Lead Compounds Aromatherapy in Blood Plasma of Mice of Essential Oils Materials from Indonesian Aromatic Plants. Asian J Chem 24 (11):5124-5128.

Muchtaridi M., Musfiroh Ida I., Subarnas A., Rambia I., Suganda H., Nasrudin ME. 2014, Chemical Composition and Locomotors Activity of Essential Oils from the Rhizome, Stem, and Leaf of Alpinia malaccencis (Burm F.) of Indonesian Spices. I Appl Pharmaceu Sci 04 (01):052-056.

Muchtaridi M., Subarnas A., Apriyantono A., Mustarichie R. 2010, Identification of Compounds in the Essential Oil of Nutmeg Seeds (Myristica fragrans Houtt.) that Inhibit Locomotor Activity in Mice. I. J. Mol. Scie. 11 (11):4771-4781.

Sangat H., Roematyo. 1996. Aromatherapy Plants: A Etnopharmacology Study. Paper read at Simposium Nasional I Tumbuhan Aromatik APINMAP, at Bogor. 
Muchtaridi

Wiendah H., Subarnas A., Supriyatna S. 1999,

lecadendron), Department of Pharmacy, Study of Locomotors Inbibitor Activity of Essential Oil of Cajuput (Melalenca Universitas Padjadjaran, Jatinangor. 